\title{
Correlation between macroalgae diversity and water quality in Southwest Maluku waters
}

\author{
Marsya J. Rugebregt *, Hairati Arfah, Ferdinand Pattipeilohy \\ Deep Sea Research Center, Indonesian Institute of Sciences, Ambon, Indonesia
}

\section{ARTICLE INFO}

\author{
ABSTRACT
}

\section{Article history:}

Submitted 30 June 2020

$1^{\text {st }}$ Revision 21 July 2020

Accepted 27 July 2020

Published online 31 July 2020

\section{Keywords:}

water quality

macroalgae diversity

macroalgae species

Southwest Maluku

\begin{abstract}
Macroalgae play an important role in the ecosystem of the coastal area, serving as a shelter ground, nursery ground, and feeding ground. Macroalgae communities are directly influenced by water quality. This study aim was to determine the correlation between the macroalgae diversity and water quality in southwest Maluku waters. This research was conducted in September 2019 at seven research stations. Macroalgae samples were collected by transect method, while seawater quality was measured using Van Dorn Water Sampler. The macroalgae diversity, species composition, and dominance were determined. Water quality parameters analyzed were temperature, salinity, $\mathrm{pH}$, phosphate, nitrate, and ammonia. Correlations between macroalgae diversity and water quality were determined using principal component analysis. This study recorded 45 species of macroalgae consisting of 15 species of red algae (Rhodophyta), 6 species of brown algae (Phaeophyta), and 24 species of green algae (Chlorophyta). Diversity Index varied ranged from low to moderate categories $(0.969-2.345)$. Water quality in general is still quite good for macroalgae life. Macroalgae diversity and water quality correlate and influence each other.
\end{abstract}

(C2020 Indonesian Institute of Sciences (LIPI).

\section{Introduction}

Southwest Maluku Regency consists of 48 small and large islands including 7 outer islands. Substrate composition of the research site consists of dead coral, sand, and corals. The presence of a macroalgae community has an important role for other marine biota as a shelter and as a fishing ground. Macroalgae communities can also serve as a habitat for other marine organisms, both large and small, such as amphipods, crabs, and others marine biota. Currently, the utilization of macroalgae has been widely developed as raw materials for food, beverage, medicines, pharmaceutical, cosmetics, and as additives in the industrial process of plastic, steel, film, textile, and paper (Bedoux et al., 2014). Besides, it can also be widely exploited in the field of biotechnology and microbiology (Resita et al., 2010).

Macroalgae are generally found in a suitable place for attachment. For example, a coastal area consisting of rocks (rocky shore) is a suitable place for their lives, so we often find many macroalgae that live in this area. The

\footnotetext{
* Corresponding Author

M.J. Rugebregt: marsya.rugebregt@gmail.com
}

distribution of macroalgae in waters is caused by the compatibility of their habitat. Seaweed habitat is generally on the level of coral reefs. They stick to the hard material substrate in the form of sand, coral, dead coral fragments, or shells. Its depth starts from the lowest tidal line to about 40 meters. This algae habitat is generally on coral reefs, the distribution of macroalgae species also follows the distribution of coral reefs. Whereas for the life of coral reefs, high clarity is needed that is free from sedimentation and high salinity, which is $30 \%$ or more. Indonesian waters are getting to the east the higher the brightness and salinity, therefore the structure and condition of coral reefs are getting better and causing higher diversity of seaweed.

Water quality affects the abundance of macroalgae. Macroalgae growth is directly affected by nutrients. The light intensity and nutrients such as phosphate and nitrate are needed in the formation of proteins in photosynthesis. The study of the nutrition of certain cultivation organisms aims to get good products in quality and quantity. Supporting factors for macroalgae growth are very complex and interrelated between physical-chemical factors, such as temperature, salinity, $\mathrm{pH}$, and concentrated things like nitrogen and phosphorus 
(Nasution et al., 2013). Supply of organic material which can continuously increase nutrients in coastal waters and ultimately cause increased water fertility and can even cause eutrophication which can disturb the balance of the ecosystem. A phosphate is a form of phosphorus that can be utilized by plants and is an essential element for higher plants and algae, so this element is a limiting factor for plants and aquatic algae and greatly affects aquatic productivity. This research determine the correlation between the macroalgae diversity and water quality in southwest Maluku waters, to support for macroalgae development activities in the area.

\section{Materials and Methods}

This research was conducted in September 2019. The research location was conducted on one location in Leti Island (Liuketi) and six location in Moa Island (Siota, Kaiwatu, Tiakur, Kliss, Nyama and Patty) Southwest Maluku Regency. Map of the location was shown in Figure 1.
Macroalgae samples were collected by the quadratic transect method that is made perpendicular to the coastline towards the slope with an interval of 100 meters with 10 transects at each location (Figure 2). Every 10meter interval from the shoreline was sampled macroalgae biomass on an iron frame measuring $50 \times 50$ $\mathrm{cm}$, besides that a free collection was also carried out to obtain the types of living macroalgae growing on each substrate. Samples were collected in a plastic bag. Samples were selected and separated according to species and genus, and weighed wet weight. Then do the identification and preserved in $70 \%$ alcohol solution. The identified samples were stored in the Biology Laboratory of the Center for Deep Sea Research - LIPI. The identification of macroalgae is based on Marine algae Varieties (Bedoux et al., 2014). Diversity index was measured according to Shannon Index. Macroalgae dominance using Simpson Index (Krebs, 2001).

Water quality parameters observed were temperature, salinity, $\mathrm{pH}$, phosphate, nitrate, ammonia, and silicate. Seawater samples were taken using a Nansen tube on the

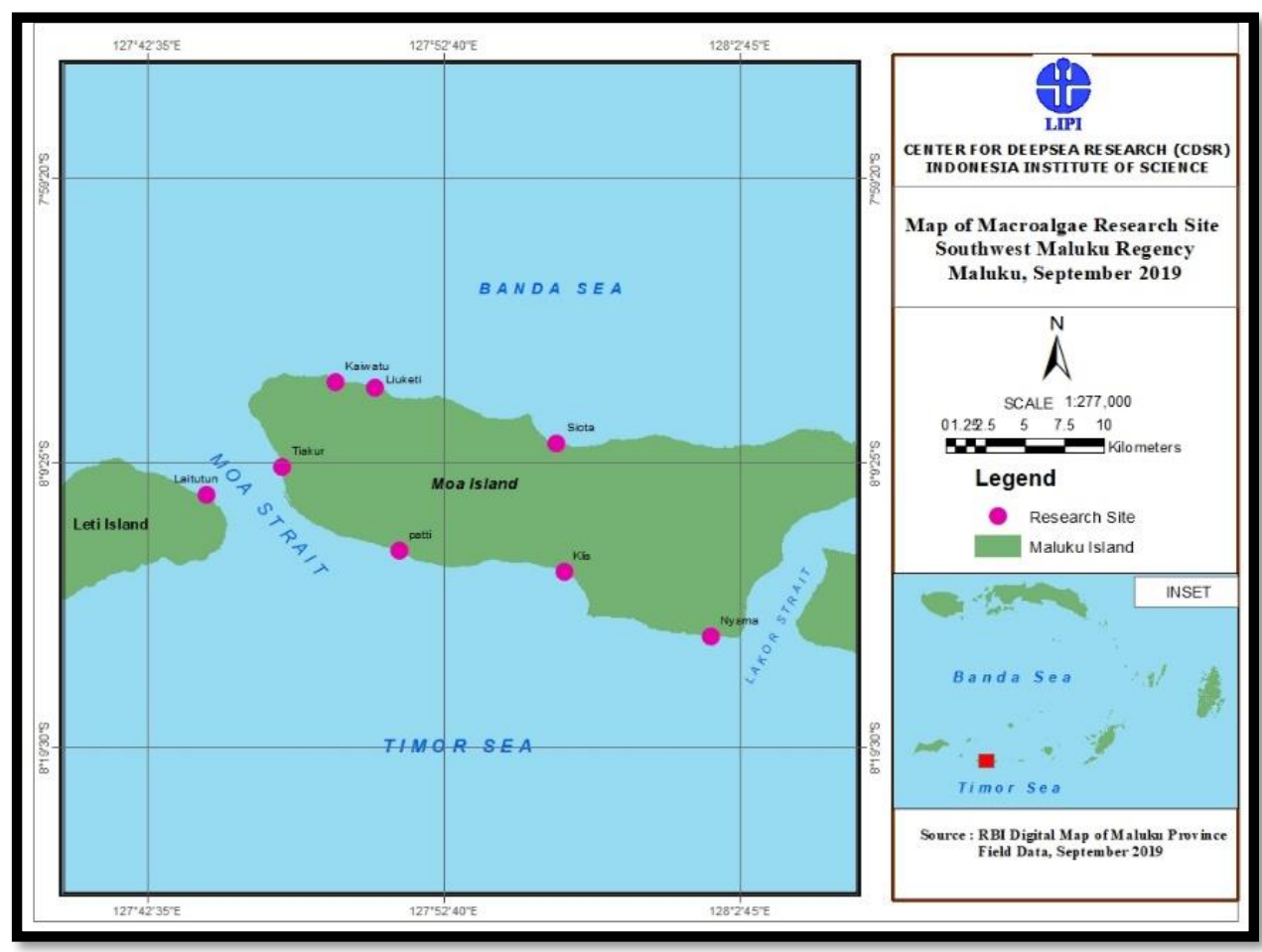

Figure 1. Map of research site in Southwest Maluku Regency, September 2019
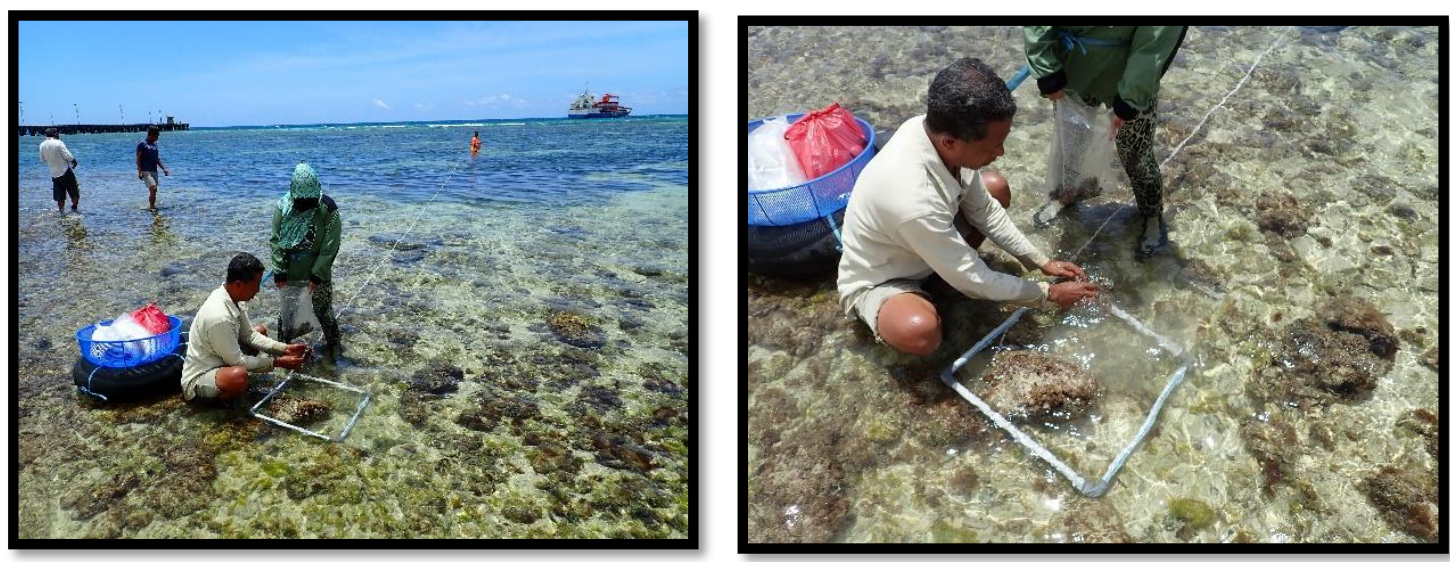

Figure 2. Field sampling using transect quadrant in Southwest Maluku Regency, 2019 
surface layer. Measurements of temperature, salinity, and $\mathrm{pH}$ are carried out in situ. Seawater temperature was measured using a GMK-910T thermometer, salinity was observed using the Atago Hand refractometer, and $\mathrm{pH}$ using a HANNA series HI9024 pH meter. Analysis of phosphate, nitrate, nitrite and ammonia according to seawater analysis (Strickland et al., 1972) based on spectrophotometric methods using UV-VIS spectrophotometer Shimadzu 1700. To find out the correlation between macroalgae diversity and water quality in the waters of Southwest Maluku used Principal Component Analysis (PCA).

\section{Results}

Macroalgae obtained from the study site in the waters 45 species consisting of 15 species of red algae (Rhodophyta), 6 species of Brown algae (Phaeophyta) and 24 species of Green algae (Chlorophyta). The most species of macroalgae were found in Leti, as many as 28 species, while the loswest species of macroalga were found in Nyama (7 species). Green algae (Chlorophyta) has the highest number of species (Figure 3 ).

The diversity index $\left(\mathrm{H}^{\prime}\right)$ obtained is shown in Table 1. The $\mathrm{H}^{\prime}$ is 2.101 in Laitutun, 2.345 in Liuketi, 1.525 in Siota, 0.969 in Tiakur, 1.859 in Klis, 1.885 in Nyama, and 1.425 in Patty (Figure 4). Siota have highest macroalgae dominance (16.13\%) even though this below in Kaiwatu



Figure 3. The number of species of macroalgae in Southwest Maluku Regency, 2019
(31.53\%) and Tiakur (16.24\%). The lowest dominance of the macroalgae is in Kliss (0.84\%), Nyama (3.55\%), Patti (5.17\%), and Leitutun (10.54\%) (Figure 5). Macroalgae density are shown in Figure 6. Hypnea has the highest density at the Tiakur village $\left(1338 \mathrm{gr} / \mathrm{m}^{2}\right)$. Tiakur village had highnest macroalgae at this study. Leitutun village $\left(2963.4 \mathrm{gr} / \mathrm{m}^{2}\right)$ had very high density. In Leitutun village, 26 of the 27 species macroalgae were found.

The water quality in Southwest Maluku Regency was presented in the following Figure 7. Temperature, salinity, and $\mathrm{pH}$ in Southwest Maluku waters not varied. Water temperature had ranges from $25.92{ }^{\circ} \mathrm{C}$ to $26.64{ }^{\circ} \mathrm{C}$. Salinity had ranges 33.56 to 33.87 . $\mathrm{pH}$ had ranges from 6.82 to 8.12 . These conditions are still good for macroalgae life.

Phosphate, nitrates, and ammonia in the Southwest Maluku waters was presented in Figure 8. The highest phosphate concentration was found in Liuketi $(0.2326$ $\mathrm{mg} / \mathrm{l})$, while the lowest phosphate concentration was found in the Siota, Kaiwatu, and Patti $(0.0465 \mathrm{mg} / \mathrm{l})$. The highest nitrate concentration was found in Liuketi $(0.0451 \mathrm{mg} / \mathrm{l})$ while nitrate concentration in Siota was undetectable. Ammonia has a high concentration in Tiakur $(0.5140 \mathrm{mg} / \mathrm{l})$ and the lowest ammonia concentration was found in Siota $(0.0699 \mathrm{mg} / \mathrm{l})$. According to the Decree of the Minister of Environment No. 51 (2004), has exceeded the standard quality for phosphate, nitrate, and ammonia were allowed.

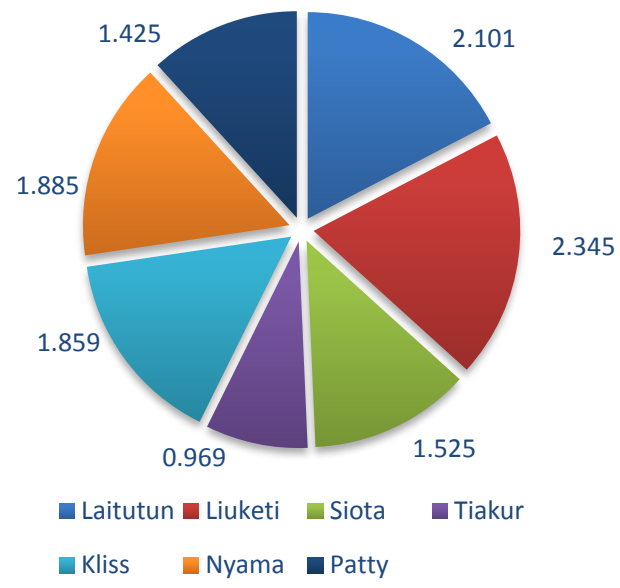

Figure 4. Diversity Index of macroalgae in Southwest Maluku Regency, 2019

Table 1. Macroalgae diversity and water quality parameters in Southwest Maluku waters, September 2019

\begin{tabular}{llllllll}
\hline Station & $\mathrm{H}^{\prime}$ & $\mathrm{pH}$ & $\mathrm{PO}_{4}$ & $\mathrm{NO}_{3}$ & $\mathrm{NH}_{4}$ & $\mathrm{Temp}$ & Salinity \\
\hline Laitutun & 2.101 & 7.16 & 0.0791 & 0.0114 & 0.2016 & 26.04 & 33.85 \\
Liuketi & 2.345 & 8.06 & 0.2326 & 0.0451 & 0.1935 & 25.96 & 33.81 \\
Siota & 1.585 & 8.12 & 0.0465 & undetectable & 0.0699 & 26.51 & 33.56 \\
Kaiwatu & 1.525 & 8.06 & 0.0465 & 0.0023 & 0.1457 & 26.64 & 33.76 \\
Tiakur & 0.969 & 6.82 & 0.0605 & 0.0171 & 0.5140 & 26.08 & 33.87 \\
Klis & 1.859 & 7.54 & 0.0605 & 0.0277 & 0.1818 & 26.06 & 33.78 \\
Nyama & 1.882 & 7.74 & 0.0558 & 0.0368 & 0.1189 & 25.92 & 33.82 \\
patti & 1.425 & 7.81 & 0.0465 & 0.0046 & 0.1480 & 26.39 & 33.75 \\
\hline min & 0.969 & 6.820 & 0.047 & 0.000 & 0.070 & 25.924 & 33.56 \\
max & 2.345 & 8.120 & 0.233 & 0.045 & 0.514 & 26.638 & 33.87 \\
average & 1.712 & 7.664 & 0.078 & 0.018 & 0.197 & 26.200 & 33.77 \\
\hline
\end{tabular}


The relationship between diversity and water quality parameters was analyzed using Principal Component Analysis. Table 2 shows the correlation between macroalgae diversity and water quality. Phosphate and nitrate have positive results that are quite consistent with variations. $\mathrm{pH}$ has a weak positive conversion but is definitely correlated with macroalgae (Niamaimandi et al.,
2017). While temperature and ammonia have a strong negative correlation to macroalgae diversity. In the current study, salinity factors correlated very weakly with macroalgae. The correlation between diverse and quality parameters of West Maluku was presented in Figure 9.

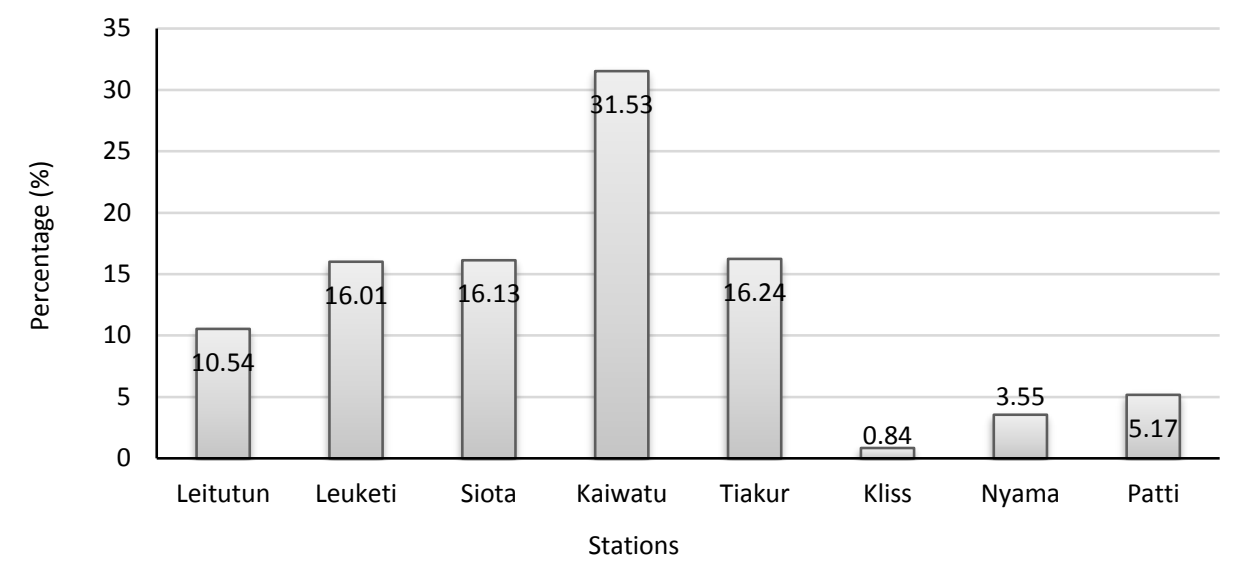

Figure 5. Macroalgae dominance, Southwest Maluku Regency, 2019

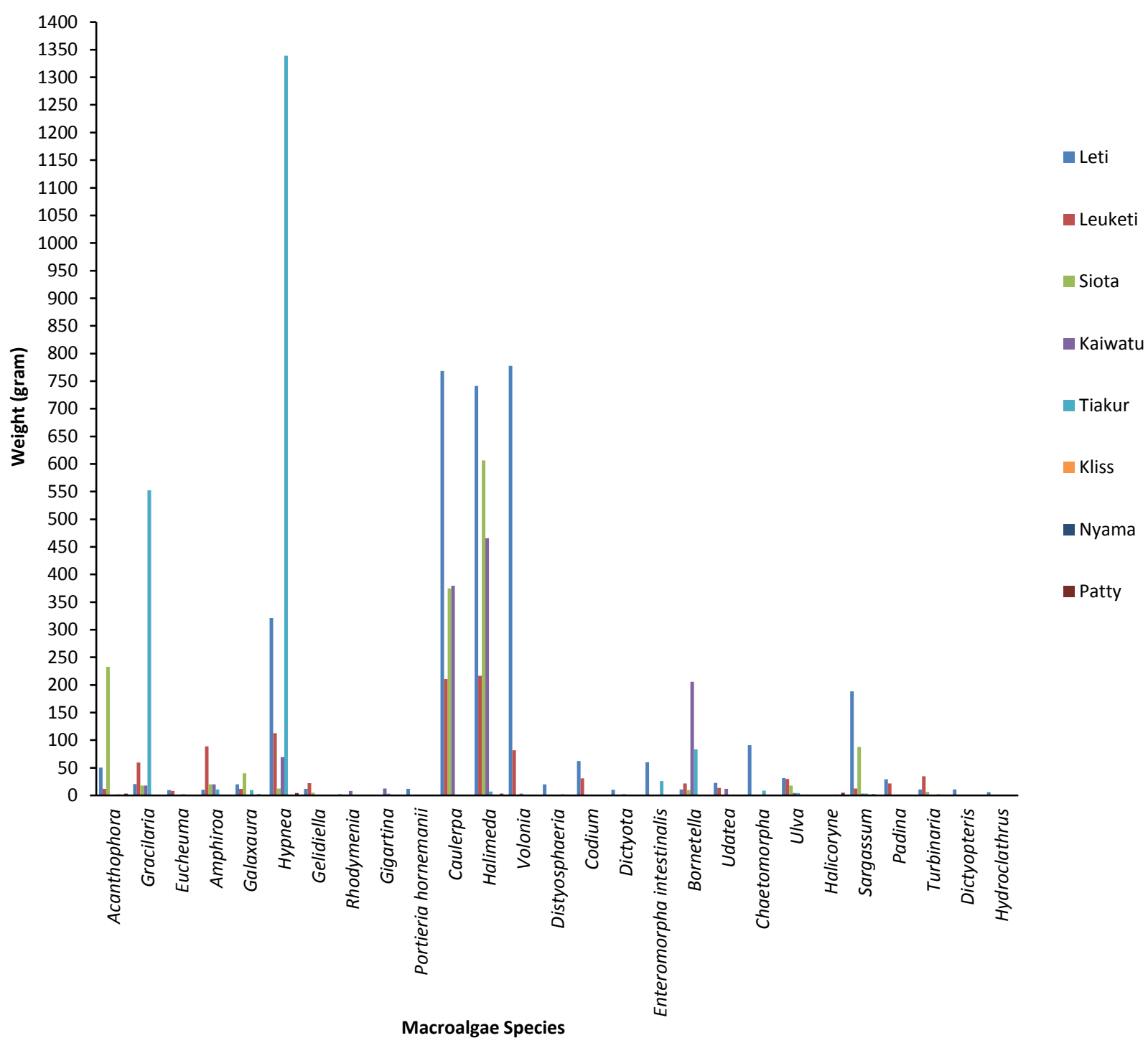

Figure 6. The density of macroalgae in Southwest Maluku Regency, September 2019 


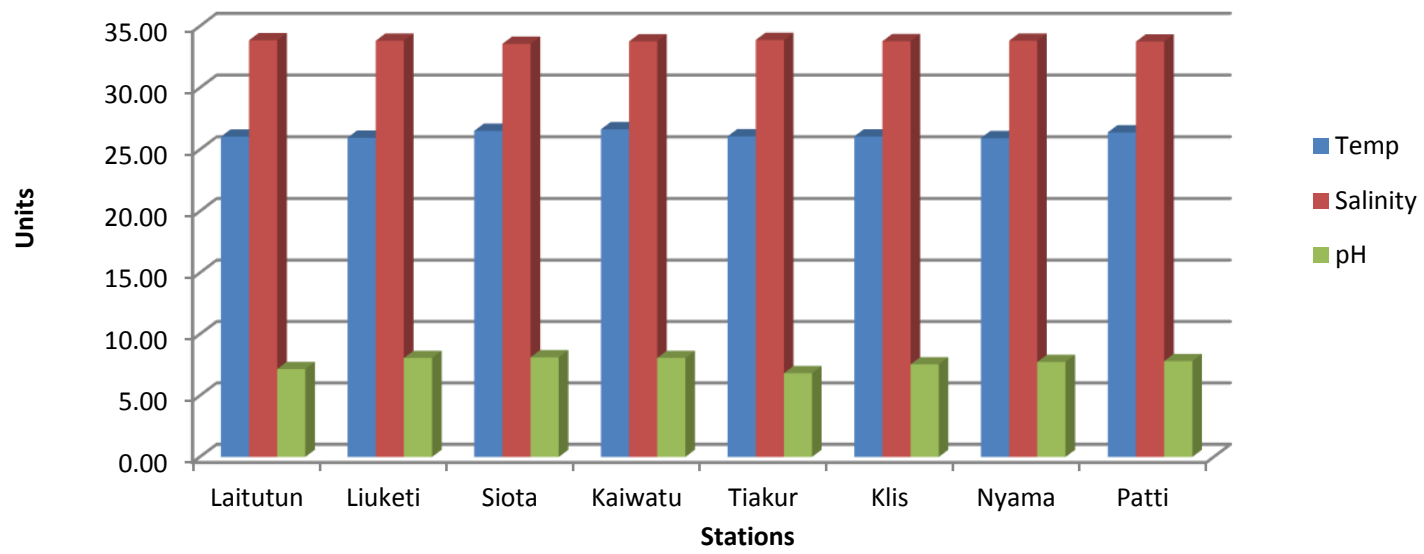

Figure 7. Macroalgae dominance, Southwest Maluku Regency, 2019

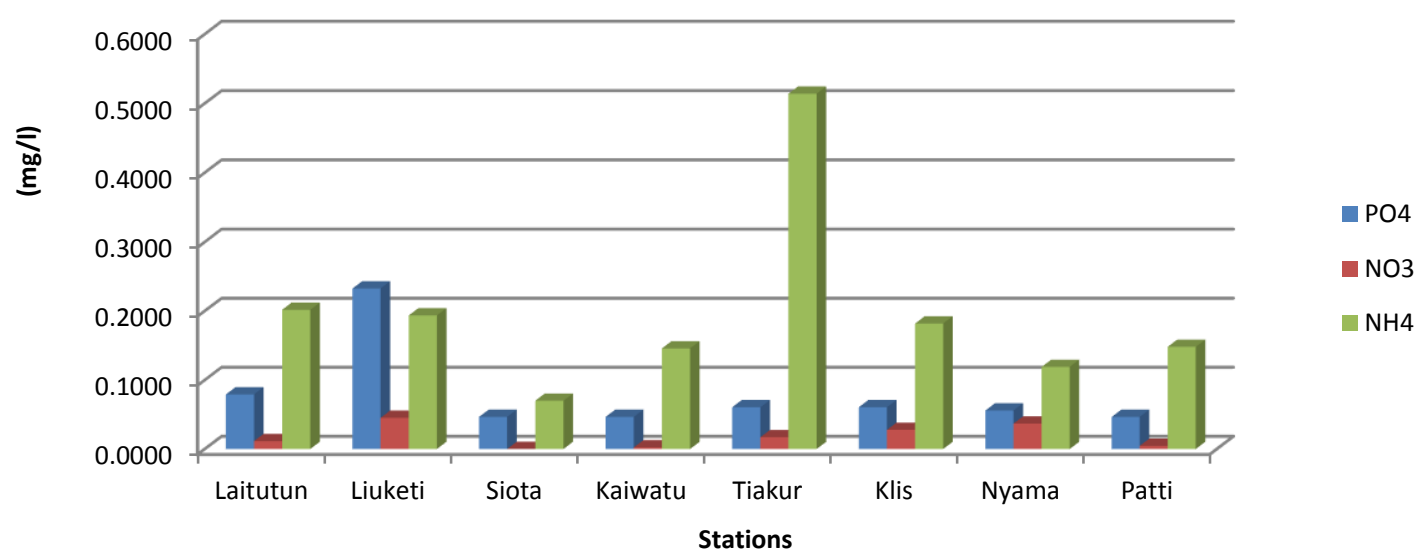

Figure 8. The density of macroalgae in Southwest Maluku Regency, September 201

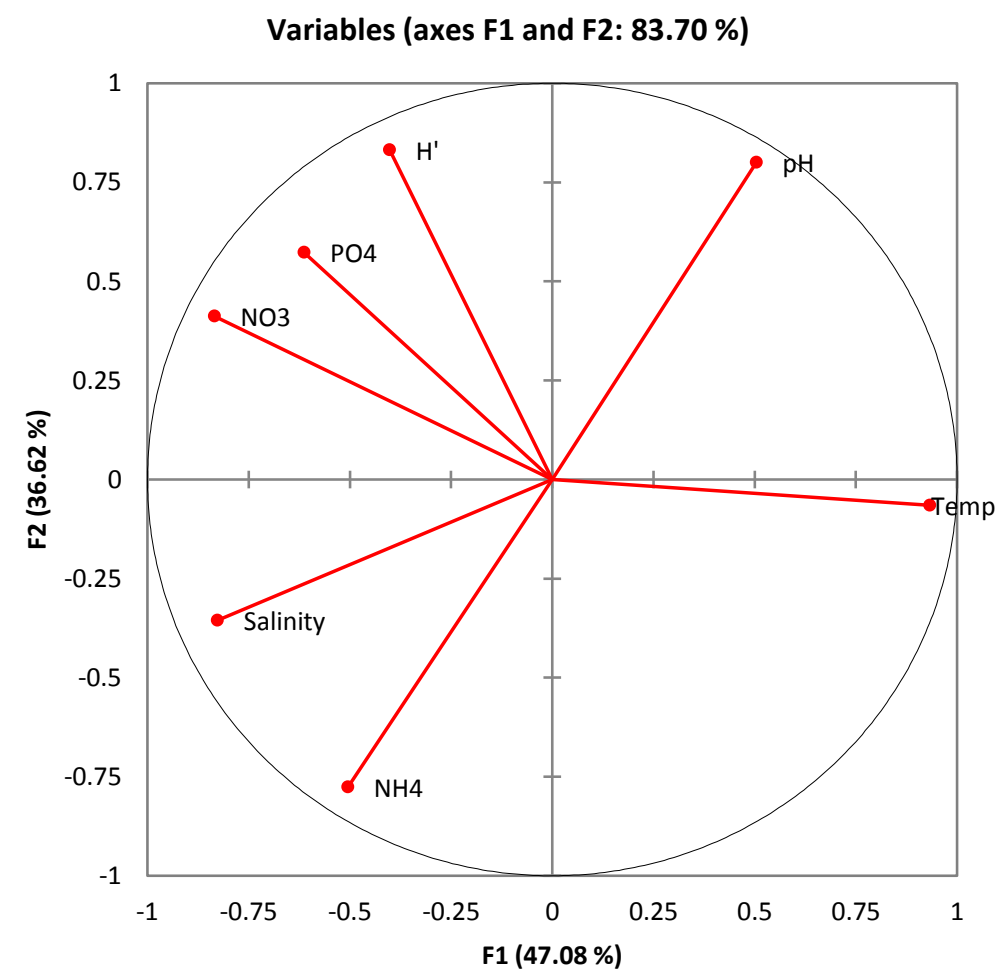

Figure 9. Correlation between macroalgae diversity and water quality in Southwest Maluku, September 2019 
Table 2. Table Correlation matrix (Pearson (n))

\begin{tabular}{lrrrrrrr}
\hline Variables & $\mathrm{H}^{\prime}$ & $\mathrm{pH}$ & $\mathrm{PO}_{4}$ & $\mathrm{NO}_{3}$ & $\mathrm{NH}_{4}$ & Temp & Salinity \\
\hline $\mathrm{H}^{\prime}$ & 1 & 0.358 & 0.652 & 0.574 & -0.521 & -0.447 & 0.084 \\
$\mathrm{pH}$ & 0.358 & 1 & 0.215 & -0.024 & -0.815 & 0.480 & -0.670 \\
$\mathrm{PO} 4$ & 0.652 & 0.215 & 1 & 0.686 & 0.051 & -0.470 & 0.262 \\
$\mathrm{NO} 3$ & 0.574 & -0.024 & 0.686 & 1 & 0.108 & -0.841 & 0.501 \\
$\mathrm{NH} 4$ & -0.521 & -0.815 & 0.051 & 0.108 & 1 & -0.338 & 0.630 \\
Temp & -0.447 & 0.480 & -0.470 & -0.841 & -0.338 & 1 & -0.675 \\
Salinity & 0.084 & -0.670 & 0.262 & 0.501 & 0.630 & -0.675 & 1 \\
\hline
\end{tabular}

Values in bold are different from 0 with a significance, level alpha $=0.05$

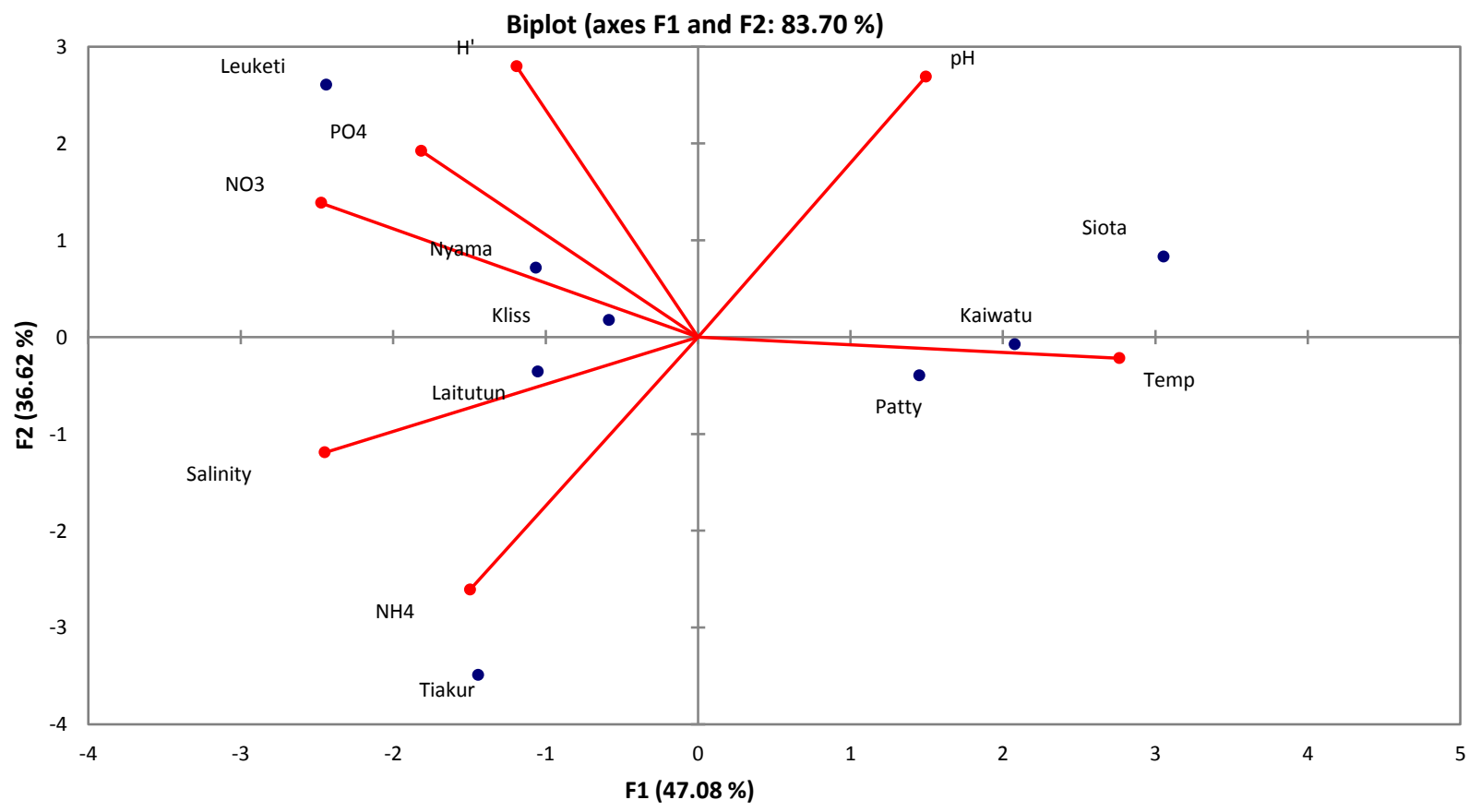

Figure 10. Grouping parameters and research sites in Southwest Maluku, September 2019

Figure 10 shows the characteristics of a research station based on its constituent parameters. Leuketi, Nyama, and Kliss were characterized by high diversity, phosphate, and nitrate. Siota was characterized by a high $\mathrm{pH}$. Tiakur and Laitutun were characterized by salinity and ammonia. Kaiwatu and Patti are characterized by high temperatures.

\section{Discussions}

Based on total phosphorus content, waters are classified into three, namely: waters with low fertility levels, which have total phosphate content from 0 to 0.02 $\mathrm{mg} / \mathrm{l}$; waters with moderate fertility, which have total phosphate levels of 0.021 to $0.05 \mathrm{mg} / \mathrm{l}$; and waters with high fertility, which have a total phosphate content of 0.051 to $0.1 \mathrm{mg} / \mathrm{l}$ (Effendi, (2003) and Joshimura in Arfah and Simon, 2016). This phosphate content range still within safe limits to life Marine biota. KMLH (2004) stipulates standard phosphate for marine biota was 0.015 $\mathrm{mg} / \mathrm{l}$. If phosphate content to the fertility category in above, then these waters belong to in the category of quite fertile and still good for macroalgae growth. $\mathrm{NO}_{3}$ (nitrate) and $\mathrm{NH}_{4}$ (ammonium) in water can be used for plant and algal growth (D'Costa et al., 2006). Southwest Maluku Regency had lower nitrate concentrations than Poole
Harbour, England (Franklin et al., 2020). Nitrate needs for macroalga varied. Nitrate content ranging from 0.9 to 3.5 $\mathrm{m} / \mathrm{l}$ is the optimal concentration for macroalgae growth (Arizuna et al., 2014).

Temperature can affect the growth of macroalgae, namely the activity of photosynthesis. High temperatures are causing disruption of photosynthesis activity (Hill et al., 2009). Temperature was around $26.2^{\circ} \mathrm{C}\left(25.9^{\circ} \mathrm{C}\right.$ to $26.6^{\circ} \mathrm{C}$ ). The temperature was still supporting macroalgae growth. According to Dawes (1991), that the normal temperature range for macroalgae growth was $25-35^{\circ} \mathrm{C}$, High temperatures above $30^{\circ} \mathrm{C}$, will stop photosynthetic and pigments were damaged (Hill et al., 2009). Salinity at the study site was 33.56 to 33.87 . This value is still suitable for macroalgae. According to Kadi and Atmadja (1988) in Ira et al. (2018), benthic algae grow in waters with salinity 13-37. Salinity can affect the physiology and rate of macroalgae photosynthesis (Xiong \& Zhu, 2002). The average of $\mathrm{pH}$ value at the study was 7.66 (6.82-8.12). This is still suitable for macroalgae growth. According to Ira et al., (2018), pH for growth macroalgae was 7-8.5. This is also supported by the statement (Papalia \& Arfah, 2013), acidic or alkaline will endanger the survival of the organism because it will cause metabolic and respiratory disorders. pH can affect the growth of macroalgae. 
Phosphate, nitrate, $\mathrm{pH}$, and salinity had positive effect on the diversity of macroalgae in Southwest Maluku waters. Increasing the concentration of phosphate, nitrate, $\mathrm{pH}$, and salinity increase the diversity of macroalgae (Fried et al., (2003); Lee et al., (2010); Rybak, (2018)). In contrast, temperature and ammonia will degrade the diversity of macroalgae in Southwest Maluku waters (Werner et al., (2016). The maximum ammonium concentration allowable in seawater is $0.05 \mathrm{mg} / \mathrm{l}$ (Sabri et al., 2017), According to Sabri et al., (2017), ammonium is the chemical form of the mineral nitrogen preferentially assimilated by the algae even in the presence of nitrate. Also, deleterious level of algal decomposition in waters produces ammonium and could contribute to the increase of its concentration

\section{Conclusion}

Southwest Maluku waters had low to medium categories of macroalgae diversity (0.969 - 2.345). Generally, water quality in Southwest Maluku waters is good for macroalgae life. The diversity of macroalgae species had a positive correlation and a negative correlation with water quality parameters. Increasing the concentration of phosphate, nitrate, $\mathrm{pH}$, and salinity increases the diversity of macroalgae. In contrast, increasing temperature, salinity, and ammonia decreased macroalgae diversity.

\section{Acknowledgement}

Briefly thank you to all those who helped until the completion of this writing. Thank you to the Deep-Sea Research Center for the funds provided sourced from DIPA 2019.

\section{References}

Arfah, H. D. S. I. P. (2016). Water Quality and Macroalga Communities in Jikumerasa Beach, Buru Island. Scientific Journal PLatax, 4(2), 109- 119.

Arizuna, M., Suprapto, D., \& Muskananfola, M. R. (2014). Nitrate and Phosphate Content in Sediment Pore Water in the River and Estuary of the Wangun Demak River. Diponegoro Journal of Maquares, 3(1), 7- 16.

Bedoux, G., Hardouin, K., Burlot, A.-S., \& Bourgougnon, N. (2014). Bioactive Components from Seaweeds: Cosmetic Applications and Future Development. In N. Bourgougon (Ed.), Advances in Botanical Research (Vol. 71, pp. 349- 382). Academic Press. https://doi.org/10.1016/B978-0-12-4080621.00012-3

D' Costa, Vanessa ; Katherine M McGrann, D. W. H. ; G. D. W. (2006). Sampling the Antibiotic Resistome. Science, 311(5759), 374- 377. https://doi.org/10.1126/science. 1120800.

Dawes, C. J. (1991). Marine Botany (Issue 1 Vo). John Wiley \& Sons, Ltd. https://doi.org/10.1163/156854083X00127

Effendi, H. (2003). Water Quality Review. Kanisius.

Franklin, D. J., Herbert, R. J. H., Chapman, I., Willcocks, A., Humphreys, J., \& Purdie, D. A. (2020). Consequences of nitrate enrichment in a temperate estuarine marine protected area; response of the microbial primary producers and consequences for management (J. Humphreys \& R. W. E. B. T.M. P. A. Clark (eds.); pp. 685- 702). Elsevier. https://doi.org/https://doi.org/10.1016/B978-0-08-1026984.00035-6.
Fried, S., Mackie, B., \& Nothwehr, E. (2003). Nitrate and phosphate levels positively affect the growth of algae species found in Perry Pond. Tillers, 4.

Hill, R., Ulstrup, K. E., \& Ralph, P. J. (2009). Temperature induced changes in thylakoid membrane thermostability of cultured, freshly isolated, and expelled zooxanthellae from scleractinian corals. Bulletin of Marine Science, 85(3), 223244.

Ira, I., Rahmadani, R., \& Irawati, N. (2018). Composition of Macroalga Types in South Sulawesi Island Waters (Species Composition of Macroalgae in Hari Island, South East Sulawesi). Journal of Tropical Biology, 18(2). https://doi.org/10.29303/jbt.v18i2.770

Krebs, C. J. (2001). Ecology the Experimental Analysis of Distribution and Abudance (5th ed.). Animprint of Addison Wesley Longman.

Lee, J.-H., Lee, D.-G., Park, J.-I., \& Kim, J.-Y. (2010). Bio-hydrogen production from a marine brown algae and its bacterial diversity. Korean Journal of Chemical Engineering, 271), 187- 192. https://doi.org/10.1007/s11814-009-0300-x

Nasution, Afiah; Niniek, W. F. P. (2013). Analysis of Phytoplankton Abundance Relationship with Nitrate and Phosphate in Morosari Waters, Demak. Journal of Chemical Information and Modeling, 53(9), 1689- 1699. https://doi.org/10.1017/СВ09781107415324.004

Niamaimandi, N., Bahmyari, Z., Sheykhsagha, N., Kouhgardi, E., \& Vaghei, R. G. (2017). Species diversity and biomass of macroalgae in different seasons in the northern part of the Persian Gulf. Regional Studies in Marine Science, 15(August 2018), 26- 30. https://doi.org/10.1016/j.rsma.2017.07.001

Papalia, Saleh ; Hairati, A. (2013). Macroalgae biomass productivity in the Ambalu waters, South Buru Regency. Journal of Tropical Marine Science and Technology, 5(1), 15. https://doi.org/10.1007/s13398-014-0173-7.2

Resita, D., Merdekawati, W., Susanto, A. B., \& Limantara, L. (2010). The Content and Pigment Composition of Sargassum sp. in Awur Bay. J Fish Sci, XII (1), 11- 19.

Rybak, A. S. (2018). Species of Ulva (Ulvophyceae, Chlorophyta) as indicators of salinity. Ecological Indicators, 85, 253- 261. https://doi.org/https://doi.org/10.1016/j.ecolind.2017.10.061 .j.ecolind.2017.10.061.

Sabri, H., Cherifi, O., Maarouf, A., Cheggour, M., Bertrand, M., \& Mandi, L. (2017). Wastewater impact on macroalgae biodiversity in Essaouira coast (Morocco). Journal of Materials and Environmental Science, 8(3), 857- 862.

Strickland, J. D. H., Parsons, T. R., \& Fisheries Research Board of Canada. (1972). A practical handbook of seawater analysis (2nd ed.). Information Canada.

Decree of the Minister of Environment No. 51. Sea Water Quality Standards, 1 (2004).

Werner, F. J., Graiff, A., \& Matthiessen, B. (2016). Temperature effects on seaweed-sustaining top-down control vary with season. Oecologia, 180(3), 889-901. https://doi.org/10.1007/s00442-015-3489-x

Xiong, L. J.-K. Z. (2002). Molecular and Genetic Aspects of Plant Responses to Osmotic Stress. Plant Cell Environ, 25(2), 131139. https://doi.org/10.1046/j.1365-3040.2002.00782.x

\section{Declarations}

\section{Funding statement}

This research did not receive any specific grant from funding agencies in the public, commercial, or not-for-profit sectors.

\section{Conflict of interest}

The authors declare no conflict of interest. 


\section{Additional information}

Reprints and permission information is available at https://mri.lipi.go.id
Publisher's Note: Indonesian Institute of Sciences remains neutral with regard to jurisdictional claims in published maps and institutional affiliations. 